\title{
Hukuman Tambahan Berupa Pembayaran Ganti Rugi bagi Pelaku Tindak Pidana Korupsi dalam Undang-Undang Tipikor Perspektif Hukum Pidana Islam
}

\author{
Riva Luviana ${ }^{1}$ \\ ${ }^{1}$ Fakultas Syariah, IAIN Jember. E-mail: rivaluviana@gmail.com
}

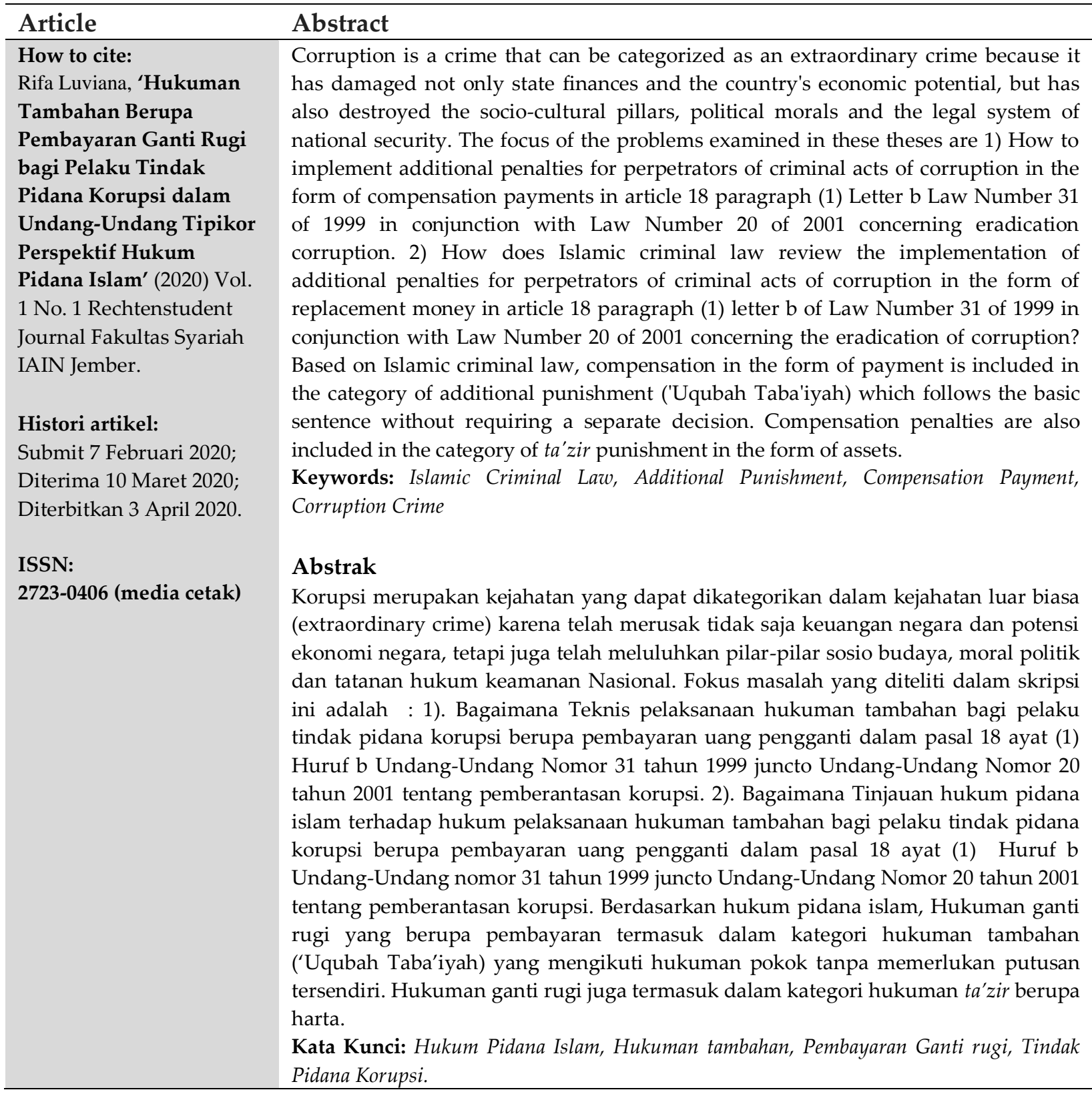




\section{Pendahuluan}

Negara Indonesia adalah Negara hukum sebagaimanaa diatur dalam Undang-Undang Negara Kesatuan Republik Indonesia Tahun 1945 khususnya dalam Pasal 1 ayat (3). ${ }^{1}$ Hal ini mengandung arti bahwa di dalam Negara Kesatuan Republik Indonesia (NKRI) hukum merupakan "Panglima" dan urat nadi pada segala aspek kehidupan bernegara maupun bermasyarakat.

Masyarakat dan ketertiban merupakan dua hal yang berhubungan sangat erat, bahkan bisa juga dikatakan sebagai dua sisi dari satu mata uang. Susah untuk mengatakan, adanya masyarakat tanpa ada suatu ketertiban. Ketertiban dalam masyarakat diciptakan bersamasama oleh berbagai lembaga, seperti hukum dan tradisi. Oleh karena itu, dimasyarakat akan dijumpai berbagai macam pedoman, patokan atau ukuran yang masing-masing memberikan kontribusinya dalam menciptakan ketertiban. Pedoman, patokan, atau ukuran untuk berperilaku atau bersikap dalam kehidupan bersama disebut norma atau kaidah sosial. Di antaranya adalah norma hukum.

Hukum menetapkan apa yang harus dilakukan dan atau apa yang boleh dilakukan serta yang dilarang. Sasaran Hukum yang hendak dituju bukan saja orang-orang yang nyata-nyata berbuat melawan hukum, melainkan juga perbuatan hukum yang mungkin akan terjadi, dan kepada alat perlengkapan negara untuk bertindak menurut hukum. ${ }^{2}$

Salah satu tindak pidana yang dapat dikatakan fenomenal adalah masalah korupsi. Dalam tindak pidana korupsi yang paling menonjol ialah, memperkaya diri, menyalahgunakan jabatan atau kedudukan, dan merugikan keuangan dan perekonomian negara. ${ }^{3}$ Tindak pidana ini tidak hanya merugikan keuangan negara, tetapi juga merupakan pelanggaran terhadap hak-hak sosial dan ekonomi masyarakat di berbagai belahan dunia korupsi selalu mendapatkan perhatian yang lebih dibandingkan dengan tindak pidana yang lainnya.

Korupsi bukanlah hal yang asing lagi di negeri ini. Korupsi di Indonesia sudah tergolong extra ordinary crime ${ }^{4}$, karena telah merusak tidak saja keuangan Negara dan potensi ekonomi Negara, tetapi juga telah meluluhkan pilar-pilar sosio budaya, moral politik dan tatanan hukum keamanan nasional. ${ }^{5}$

Lahirnya Undang-Undang Nomor 31 tahun 1999 juncto Undang-Undang Nomor 20 tahun 2001 tentang pemberantasan Tindak Pidana Korupsi sebagai Pengganti UndangUndang Nomor 3 tahun 1971 dimaksudkan untuk mempercepat pemberantasan tindak pidana korupsi di Indonesia. Adanya perubahan baik hukum materil maupun hukum formal serta ditingkatkannnya ancaman pidana dalam undang -undang Nomor 31 tahun 1999 Juncto Undang-Undang Nomor 20 tahun 2001 tentang pemberantasan tindak pidana korupsi . merupakan upaya pemerintah untuk memusnahkan tindak pidana korupsi yang semakin bertambah. Akan tetapi, Usaha pemerintah memberantas tindak pidana korupsi di Indonesia

\footnotetext{
${ }^{1}$ Undang-Undang Negara Republik Indonesia Tahun 1945 pasal 1 ayat (3)

2 Evi Hartani, Tindak Pidana Korupsi ( Jakarta : Sinar Grafika , 2008), 1.

${ }^{3}$ Wirjono Prodjpdikoro, Tindak-Tindak Pidana Tertentu Di Indonesia, (Bandung : PT Refika Aditama, 2003 ) , 251.

${ }^{4}$ Extra ordinary crime dalam bahasa indonesia berarti kejahatan luar biasa. Korupsi merupakan kejahatan luar biasa yang dasarnya adalah konsideran menimbang dari UU No. 20 tahun 2001 tentang perubahan dari undangundang nompr 31 tahun 1999 yang menayatakan bahwa penanagan kasus korupsi masih menggunakan usaha yang extra atau luar biasa.

${ }^{5}$ Ermanjah Djaja, Memberantas Korupsi Bersama KPK (Komisi Pemberantasan Korupsi), (Bandung: PT Refika Aditama, 2008), 5 .
} 
yang sudah mengakar ke berbagai lapisan tidaklah mudah seperti membalikkan telapak tangan.

Dalam pelaksanaan putusan pidana pasal $10 \mathrm{KUHP}$ mengatur tentang jenis pidana yang dapat dijatuhkan kepada terdakwa tindak pidana korupsi yaitu tindak pidana pokok dan tindak pidana tambahan. Pidana pokok dalam pasal tersebut terdiri dari pidana mati, pidana penjara, pidana kurungan dan pidana denda. Sedangkan pidana tambahan terdiri dari pencabutan hak-hak tertentu.

Dalam kaitannya dengan hukuman tambahan bagi pelaku tindak pidana korupsi, pembayaran ganti kerugian dalam kasus tindak pidana korupsi termasuk dalam pidana tambahan selain putusan penjatuhan hukuman pidana dan denda. Pidana tambahan dalam tindak pidana korupsi sebagaimana diatur dalam pasal 18 ayat 1 huruf $b$ Undang- Undang Nomor 31 tahun 1999 Juncto Undang-Undang Nomor 20 tahun 2001 tentang pemberantasan tindak pidana korupsi. ${ }^{6}$

Didalam ketentuan hukum pidana Islam, Islam menetapkan aturan hukum syari'at, yang mana tujuan utama syari'at Islam ialah untuk menjaga dan melindungi lima sasaran pokok atau populer dengan istilah al-maqasid al-shari'ah, yaitu perlindungan terhadap jiwa ((hifz al mal), perlindungan terhadap agama (hifz al-din), perlindungan terhadap akal (hifz al'aql), perlindungan terhadap keturunan (hifz al-nasl), dan perlindungan terhadap harta (hifz almal).Tindak pidana korupsi jelas merupakan perlawanan terhadap tujuan ke lima (hifz al-mal) Apabila dalam kepustakaan hukum islam, contoh populer perbuatan hifz al-mal ini adalah kejahatan mencuri ( al-sariqah) milik perorangan . namun korupsi (al-ikhtilas) merupakan salah satu tindak kejahatan harta, yaitu memakan harta manusia dengan cara yang bathil.

Hukuman bagi pelakuTindak pidana korupsi didalam hukum pidana islam tidak tiadatur dalam nash, hal ini bukan berarti tindakmdana korupsi bebas dari hukuman. Hukuman yang tidak diataur secara nash dapat digantikan dengan Ta'zir Hukuma Taa'zir banyak Jumlahnnya, yang di mulai dari hukuman yang paling ringan sampai yang paling berat. Didalam hukum pidana islam juga terdapat beberapa macam hukuman.

\section{Rumusan Masalah}

Adapun rumusan masalah dalam penelitian ini adalah:

1. Bagaimana teknis pelaksanaan hukuman tambahan berupa pembayaran uang pengganti bagi pelaku tindak pidana korupsi dalam pasal 18 ayat (1) Huruf b Undang-Undang nomor 31 tahun 1999 juncto Undang-Undang Nomor 20 tahun 2001 tentang pemberantasan tindak pidana korupsi?

2. Bagaimana Tinjauan hukum pidana islam terhadap hukum pelaksanaan hukuman tambahan bagi pelaku tindak pidana korupsi berupa pembayaran uang pengganti dalam pasal 18 ayat (1) Huruf b Undang-Undang nomor 31 tahun 1999 juncto UndangUndang Nomor 20 tahun 2001 tentang pemberantasan tindak pidana korupsi?

\section{Metode Penelitian}

Pendekatan yang dilakukan dalam peneltian ini adalah yang pertama pendekatan konseptual (conceptual Appoarch) dan yang kedua pendekatan Perundang-undangan (Statute Appoarch). Yang pertama pendekatan konseptual ialah (conceptual Appoarch) yakni sebuah

\footnotetext{
${ }^{6}$ Undang-Undang Nomor 31 tahun 1999 Juncto Undang-Undang Nomor 20 tahun 2001 tentang Pemberantasan tindak pidana korupsi
} 
pendekatan yang mencoba untuk mengkonsepsikan tentang hukuman tambahan bagi pelaku tindak pidana korupsi dalam pasal 18 ayat (1) huruf b Undang-Undang Nomor 31 tahun 1999 Juncto Undang-Undang Nomor 20 tahun 2001 tentang pemberantasan tindak pidana korupsi dan tinjaunnya dalam hukum pidana islam. Yang kedua pendekatan undang-undang (Statuta Appoarch) dalam penelitian normatif harus menggunakan perundang-undangan, karena yang akan diteliti adalah aturan-aturan hukum yang menjadi fokus sekaligus tema sentral dalam suatu penelitian.

Jenis penelitian yang akan digunakan dalam penelitian ini menggunakan jenis penelitian hukum normatif atau disebut dengan penelitian hukum kepustakaan. Dalam penelitian kualitatif, penelitian ini biasa disebut dengan jenis penelitian kepustakaan, atau Library Research. Pada penelitian hukum Normatif ini peneliti melihat pada Undang-Undang No 31 tahun 1999 tentang tindak pidana korupsi yang sekarang dirubah menjadi Undang-Undang Nomor 20 tahun 2001 tentang tindak pidana korupsi.

Sumber hukum Utama Data primer yang di gunakan ialah Undang- Undang Nomor 31 tahun 1999, sebagaimana yang telah di rubah menjadi Undang-Undang Nomor 20 tahun 2001 tentang pemberantasan tindak pidana korupsi, Peraturan Mahkamah Agung Republik Indonesia Nomor 5 tahun 2014 tentang pidana tambahan uang pengganti bagi pelaku tindak pidana korupsi. Untuk data Sekunder. Data-datanya diperoleh dari bahan yang memberikan penjelasan mengenai hukum-hukum pada sumber primer Seperti buku-buku yang membahas tema-tema tentang korupsi, dan jurnal-jurnal ilmiah yang mebahas tentang korupsi, KitabKitab tentang jinayah dalam penelitian ini kitab jinayah yang digunakan adalah kitab TAsyri' Al- jina'I yang ditulis oleh Abdul Qadir Audah dan buku-buku hukum pidana islam. kitab Undang-Undang hukum pidana dan sumber lain yang relevan dengan penelitian.

\section{Hasil dan Pembahasan}

\section{Penerapan Hukuman Tambahan Berupa Pembayaran Ganti Rugi terhadap Pelaku Tindak Pidana Korupsi}

Setelah melakukan penelitian, peneliti dapat mendeskripsikan bahwa mekanisme tradisi Dalam salah satu unsur dari tindak pidana korupsi terdapat unsur dapat merugikan keuangan dan perekonomian negara. Unsur inilah yang menjadi sebab bahwa pelaku tindak pidana korupsi harus membayar uang penggati sebagai hukuman tambahan atas korupsi yang dilakukanya.

Pidana tambahan memiliki beberapa perbedaan dengan pidana pokok yaitu?:

a) Penjatuhan salah satu jenis pidana pokok adalah suatu keharusan atau imperatif. Sedangkan penjatuhan pidana tambahan bersifat fakultatif. Apabila dalam suatu persidangan terbukti bahwa terdakwa bersalah secara sah dan meyakinkan maka hakim harus menjatuhkan salah satu pidana pokok sesuai jenis dan batas maksimum dari rumusan tindak pidana yang dilanggar tersebut. Sifat imperatif yaitu diancamkan pada rumusan tindak pidana, dimana terdapat dua kemungkinan yaitu diancamkan salah satu pidana pokok sehingga hakim mau tidak mau harus menjatuhkan pidana sesuai rumusan tersebut atau dapat juga tindak pidana yang diancam oleh dua atau lebih jenis pidana pokok sehingga hakim dapat memilih salah satu saja. Misalnya pada pasal 2 ayat (2) Undang-Undang Pemberantasan Tindak Pidana Korupsi memilih jenis pidana seumur hidup atau selama waktu tertentu antara empat tahun hingga 20 tahun.

\footnotetext{
${ }^{7}$ Barda Nawawi arief, Perbandingan Hukum Pidana, (Jakarta: PT RajaGrafindo Persada, 2005). 23.
} 
Pada pidana tambahan hakim boleh menjatuhkan atau tidak pidana tambahan yang diancamkan terhadap si pelanggar. Misalnya, hakim dapat menjatuhkan salah satu pidana tambahan pasal - pasal 18 ayat (1) Undang-Undang Pemberantasan Tindak Pidana Korupsi dalam hal terbukti melanggar pasal 3 Undang-Undang Pemberantasan Tindak Pidana Korupsi. Walaupun prinsipnya penjatuhan pidana tambahan adalah fakultatif tetapi terdapat beberapa pengecualian misalnya pasal 250 bis KUHP

b) Penjatuhan jenis pidana pokok harus bersamaan dengan pidana tambahan (berdiri sendiri) sedangkan penjatuhan pidana tambahan harus bersamaan dengan pidanapokok.

c) Jenis pidana pokok yang dijatuhkan, bila telah mempunyai kekuatan hukum tetap diperlakukan pelaksanaan (executie) sedangkan pidana tambahan tidak. Pada pidana pokok, diperlukan eksekusi terhadap pencapaian pidana tersebut kecuali pidana pokok dengan bersyarat (pasal 14a) dan syarat yang ditentuan itu tidak dilanggar. Pada pidana tambahan misalnya pidana pengumuman putusan hakim.

d) Pidana pokok tidak dapat dijatuhkan kumulatif sedangkan pidana tambahan dapat. Akan tetapi dapat disimpangi pada beberapa Undang-Undang termasuk UndangUndang Pemberantasan Tindak Pidana Korupsi.

Definisi pidana pembayaran uang pengganti dapat ditarik dari pasal 18 UndangUndang ayat 1 huruf b Nomor 31 Tahun 1999 yaitu : "Pembayaran uang pengganti yang jumlahnya sebanyak-banyaknya sama dengan harta benda yang diperoleh dari tindak pidana korupsi". ${ }^{8}$ Untuk dapat menentukan dan membuktikan berapa sebenarnya jumlah harta benda yang diperoleh terpidana dari tindak pidana korupsi jangan hanya ditafsirkan harta benda yang masih dikuasai oleh terpidana pada saat jatuhnya putusan pengadilan tetapi juga harta benda hasil korupsi yang pada waktu pembacaan $\mathrm{p}$ utusan sudah dialihkan terdakwa kepada orang lain

Hukuman tambahan dalam tindak pidana korupsi tertera dalam Pasal 18 UndangUndang Nomor 20 Tahun 2001 tentang Pemberantasan Tindak Pidana Korupsi berbunyi sebagai berikut: ${ }^{9}$

1. Selain pidana tambahan sebagaimana dimaksud dalam Kitab Undang-Undang Hukum Pidana, sebagai pidana tambahan:

a. Perampasan barang bergerak yang berwujud atau yang tidak berwujud atau barang tidak bergerak yang digunakan untuk atau yang diperoleh dari tindak pidana korupsi, termasuk perusahaan milik terpidana dimana tindak pidana korupsi dilakukan, begitu pula harga dari barang yang menggantikan barang-barang tersebut;

b. Pembayaran uang pengganti yang jumlahnya sebanyak-banyaknya sama dengan harta benda yang diperoleh dari tindak pidana korupsi;

c. Penutupan seluruhnya atau sebagian perusahaan untuk waktu paling lama 1 (satu) tahun;

d. Pencabutan seluruh atau sebagian hak- hak tertentu atau penghapusan seluruh atau sebagian keuntungan tertentu, yang telah atau dapat diberikan oleh pemerintah kepada terpidana.

2. Jika terpidana tidak membayar uang pengganti sebagaimana dimaksud dalam ayat (1)

\footnotetext{
${ }^{8}$ Undang-Undnag Nomor 31 tahun 1999 Jo Undang-Undang No 20 tahun 2001 pasal 18 ayat (1) huruf b

${ }_{9}^{9}$ Undang-Undang Nomor 20 Tahun 2001 tentang pemberantasan tindak pidana korupsi
} 
huruf b paling lama dalam waktu 1 (satu) bulan sesudah putusan pengadilan yang telah memperoleh kekuatan hukum tetap, maka harta bendanya dapat disita oleh jaksa dan dilelang untuk menutupi uang pengganti tersebut.

3. Dalam hal terpidana tidak mempunyai harta benda mencukupi untuk membayar uang pengganti sebagaimana yang dimaksud dalam ayat (1) huruf $b$, maka dipidana dengan pidana penjara yang lamanya tidak melebihi ancaman maksimum dari pidana pokoknya sesuai dengan ketentuan dari undang-undang ini dan lamanya pidana tersebut sudah ditentukan dalam putusan pengadilan.

Berhubung dengan tidak adanya upaya sanksi jika uang pengganti tidak dibayar di dalam Undang-Undang Pemberantasan Tindak Pidana Korupsi 1971, jadi pada ayat (2) pasal 18 UU Pemberantasan Tindak Pidana Korupsi 2001 tersebut, dicantumkan "jika terpidana tidak membayar uang pengganti sebagaimana dimaksud ayat (1) huruf b paling lama dalam waktu satu bulan sesudah putusan pengadilan yang telah memperoleh hukum tetap, maka harta bendanya dapat disita oleh jaksa dan dilelang untuk menutupi uang pengganti tersebut."

Pada ayat (3) diatur jika terpidana tidak mempunyai harta yang mencukupi untuk membayar uang pengganti, mereka dipidana dengan pidana penjara yang lamanya tidak melebihi ancaman maksimum dari pidana pokoknya, yang lamanya sudah ditentukan di dalam putusan pengadilan. ${ }^{10}$ Pidana pembayaran uang pengganti dan pidana denda memiliki sifat yang berbeda hal ini dapat dilihat bahwasanya pidana uang pengganti merupakan pidana tambahan sedangkan pidana denda merupakan pidana pokok. walaupun jaksa tidak dapat memperpanjang tenggang waktu pembayaran tetapi mengingat bunyi pasal 18 ayat (2) Undang-Undang Pemberantasan Tindak Pidana Korupsi maka jaksa masih dapat menentukan tahap-tahap pembayaran uang pengganti, tetapi tetap tidak melebihi tenggang waktu satu bulan tersebut. Dalam hal melakukan penyitaan terhadap harta benda terdakwa hendaknya mengikuti tata cara penyitaan yang diatur dalam penerapan eksekusi pembayaran uang pengganti menurut Fatwa Mahkamah Agung RI Nomor: 37/T4/88/66/Pid tanggal 12 Januari 1988 yang antara lain:

1. Barang-barang terpidana yang masih ada disita untuk kemudian dijual secara lelang guna memenuhi kewajiban pidana pembayaran uang pengganti;

2. Penyitaan hendaknya dikecualikan atas barang-barang yang dipakai sebagai penyanggah mencari nafkah terpidana dan keluarganya

3. Penyitaan hendaknya menghindari kesalahan penyitaan terhadap barang bukan milik terpidana agar jangan sampai terjadi perlawanan dari pihak ketiga. ${ }^{11}$

Pasal 18 ayat (3) Undang-Undang Pemberantasan Tindak Pidana Korupsi ditentukan dalam hal terpidana tidak mempunyai harta benda yang mencukupi untuk membayar uang pengganti dalam tenggang waktu yang ditentukan ayat (2) maka terpidana dipidana penjara yang lamanya tidak melebihi ancaman maksimal pidana pokoknya dan pidana tersebut sudah dicantumkan dalam putusan. Pidana subsider penjara dalam pasal tersebut terlihat terdapat tiga syarat:

a. Pidana subsider baru berlaku dalam hal terpidana tidak mempunyai harta benda yang mencukupi untuk membayar uang pengganti. Terpidana dalam waktu 1 bulan setelah putusan memperoleh kekuatan hukum tetap ternyata tidak mempunyai lagi uang tunai

\footnotetext{
${ }^{10}$ Andi Hamzah. Pemberantasan Korupsi, (Jakarta : PT RajaGrafindo Persada, 2008), 119

${ }^{11}$ Fatwa Mahkamah Agung RI Nomor: 37/T4/88/66/Pid tanggal 12 Januari 1988
} 
untuk membayar uang pengganti, juga hasil lelang dari harta bendanya tidak mencukupi untuk membayar uang pengganti.

b. Lamanya pidana penjara pengganti tidak melebihi ancaman pidana maksimum dari pasal Undang- Undang Pemberantasan Tindak Pidana Korupsi yang dilanggar terdakwa.

c. Lamanya pidana penjara pengganti telah ditentukan dalam putusan pengadilan.

Dalam Pelaksanaan hukuman tambahan selain pasal 18 ayat 1 huruf b Undang- Undang Nomor 20 Tahun 20001. Peraturan Mahkamah Agung Republik Indonesia Nomor 5 Tahun 2014 juga Mengatur Tentang Pidana Tambahan Uang Pengganti Dalam Tindak Pidana Korupsi ${ }^{12}$ :,

Pasal 9

(1)Apabila dalam jangka waktu 1 (satu) bulan setelah putusan berkekuatan hukum tetap, terpidana tidak melunasi pembayaran uang pengganti, Jaksa wajib melakukan penyitaan terhadap harta benda yang dimiliki terpidana.

(2)Jika setelah dilakukan penyitaan sebagaimana dimaksud ayat (1) terpidana tetap tidak melunasi pembayaran uang pengganti, Jaksa wajib melelang harta benda tersebut dengan berpedoman pada Pasal 273 ayat (3) KUHAP.

(3) Pelaksanaan lelang dilakukan selambat-lambatnya 3 bulan setelah dilakukan penyitaan.

(4)Sepanjang terpidana belum selesai menjalani pidana penjara pokok, Jaksa masih dapat melakukan penyitaan dan pelelangan terhadap harta milik terpidana yang ditemukan.

Pasal 10

(1)Penjara pengganti yang harus dijalankan terpidana ditetapkan oleh jaksa setelah memperhitungkan uang pengganti yang telah di bayarkan sebelum pidana penjara pokoknya selesai dijalani

(2) Terpidana tetap dapat melakukan pelunasan sisa uang pengganti setelah selesai menjalankan pidana penjara pokok maupun pada saat menjalankan penjara pengganti.

(3) Pelunasan sebagaimana yang diatur dalam ayat (2) mengurangi sisa penjara pengganti sesuai dengan bagian yang dibayarnya.

\section{Pasal 11}

(1)Jaksa mengirimkan tembusan berita acara pembayaran uang pengganti yang ditandatangani olehnya dan terpidana kepada Pengadilan Negeri yang mengadili perkara.

(2)Apabila terpidana tidak memiliki harta benda lagi untuk disita, Jaksa membuat berita acara yang menyatakan hal tersebut dan ditembuskan kepada Pengadilan Negeri yang mengadili perkara.

(3)Apabila telah dilakukan pelelangan terhadap harta benda milik Terpidana sebagaimana dimaksud Pasal 10 ayat (2), Jaksa mengirimkan tembusan berita acara pelelangan tersebut kepada Pengadilan Negeri yang mengadili perkara.

(4)Dalam hal terpidana membayarkan sebagian dari uang pengganti yang dijatuhkan kepadanya, pembayaran uang pengganti tersebut akan diperhitungkan secara

\footnotetext{
12 Peraturan Mahkamah Agung Republik Indonesia Nomor 5 Tahun 2014 Tentang Pidana Tambahan Uang Pengganti Dalam Tindak Pidana Korupsi
} 
proporsional sebagai pengurangan lama penjara pengganti yang harus dijalani terpidana.

Pasal 12.

(1)Perhitungan lama penjara pengganti yang harus dijalani terpidana sebagaimana dimaksud Pasal 10 ayat (1) ditembuskan kepada Pengadilan Negeri yang mengadili perkara dan Lembaga Pemasyarakatan.

(2)Dalam hal terpidana diberikan pembebasan bersyarat, pelaksanaan pembebasan bersyarat dilakukan setelah terpidana menjalani penjara pengganti.

\section{Tinjauan Hukum Pidana Islam Terhadap Hukuman Tambahan Bagi Pelaku Tindak} Pidana Korupsi

Jarimah Korupsi dalam hukum pidana islam, hukumannya berbentuk ta'zir karena belum diatur dalam syara'. Dan tidak dapat dikategorikan dalam jarimah sariqah dan jarimah hirabah, karena tidak memenuhi unsur pada keduanya. Hukuman ta'zir adalah hukuman untuk jarimah-jarimah ta'zir. Jarimah ta'zir jumlahnya sangat banyak, karena mencakup semua perbuatan maksiat yang hukumannya belum ditentukan oleh syara' dan diserahkan kepada ulil amri untuk mengaturnya.

Hukuman $t a^{\prime} z i$ ini jumlahnya cukup banyak, mulai dari hukuman yang paling ringan sampai yang paling berat. Dalam penyelesaian perkara yang termasuk jarimah $t a^{\prime} z i r$ hakim diberi kewenangan untuk memilih diantara kedua hukuman tersebut. Mana yang paling sesuai dengan jarimah yang dilakukan oleh pelaku. Secara garis besar hukuman ta'zir dapat dikelompokkan menjadi empat kelompok:

1) Hukuman $t a^{\prime} z i r$ yang mengenai badan, seperti hukuman mati dan jilid.

2) Hukuman yang berkaitan dengan kemerdekaan seseorang, seperti hukuman penjara dan pengasingan.

3) Hukuman yang berkaitan dengan harta, seperti denda, penyitaan atau perampasan harta, dan penghancuran barang.

4) Hukuman-hukuman lain yang ditentukan oleh ulil amri demi kemaslahatan umum. ${ }^{13}$

Ganti rugi dalam tindak pidana korupsi termasuk dalam bentuk hukuman $t a^{\prime} z i r$ yang ketiga yakni hukuman yang berkaitan dengan harta, seperti denda, penyitaan atau perampasan harta dan penghancuran barang. Dalam fiqih jimayah, Diyat juga merupakan denda atas orang yang melakukan bunuh dengan tidak sengaja atau atas pembunuhan yang serupa sengaja atau berbuat sesuatu pelanggaran yang memperkosa hak manusia seperti zina, melukai dan sebagainya. ${ }^{14}$ Namun menurut Fatwa MUI, mengutip dari pendapat Wahbah AlZuhaili, Nasariyah Al- Dhamam Damsyiq Dar al- Fikr, 1998 menjelaskan bahwa:

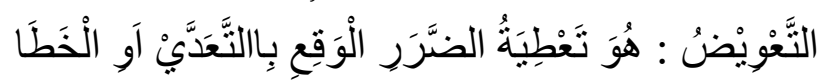

Ta'widh (ganti rugi) adalah menutup kerugian yang terjadi akibat pelanggaran atau kekeliruan. ${ }^{15}$

Namun denda dalam tindak pidana korupsi adalah sebagai takzir bukan diyat karena dalam pembayaran denda tidak berasal dari pelanggaran yang melukai atau merusak anggota badan seseorang. Denda dalam ta'zir disebut Gharamah. Di antara jarimah yang diancam

\footnotetext{
${ }^{13}$ Ahmad Wardi Muslich, Hukum Pidana Islam,(Jakarta: Sinar Grafika, 2005), 258.

${ }^{14}$ Moh Kasim Bakri, Hukum Pidana Islam, (semarang: ramadani), 12.

${ }^{15}$ Fatwa Dewan Syari'ah Nasional No. 43/DSN-MUI/VIII/2004 Tentang Ganti Rugi (Ta'widh) ب؟
} 
dengan hukuman denda adalah pencurian buah-buahan yang masih ada pohonnya. Dalam hal ini pelaku tidak dikenakan hukuman potong tangan, melainkan didenda dengan dua kali lipat harga buah-buahan yang diambil. Di samping hukuman lain yang sesuai. Hal ini dijelaskan dalam hadits nabi SAW.

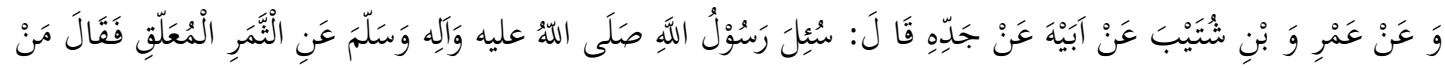

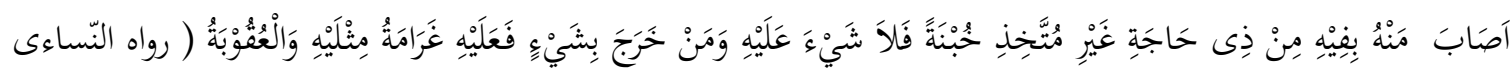

$$
\begin{aligned}
& \text { وابوداود) }
\end{aligned}
$$

Dari 'Amr ibn Syu'aib dari ayahnya dari kakeknya ia berkata: Rasulullah SAW, ditanya tentang pencurian buah-buahan yang masih menggantung di pohonnya maka beliau menjawab, “Barang siapa yang mengambilnya untuk dimakan, karena sangat membutuhkan tanpa disembunyikan (disimpan) maka ia tidak dikenakan apa-apa. Dan barang siapa yang keluar dengan membawa sesuatu maka ia dikenakan denda sebanyak dua kali barang yang diambilnya beserta hukuman lain........( HR. An- Nasai dan Abu daud).

Ditinjau dari status hukumnya, para ulama berpendapat tentang dibolehkannya hukuman $t a^{\prime} z i r$ dengan cara mengambil harta. Menurut Imam Abu Hanifah, hukuman $t a^{\prime} z i r$ degan cara mengambil harta tidak dibolehkan. Pendapat ini diikuti oleh muridnya, yaitu Muhammad Ibn Hasan, tetapi muridnya yang lain, yaitu Imam Abu Yusuf membolehkannya, apabila dipandang membawa maslahat. Pendapat ini diikuti oleh Imam Malik, Imam Syafi'i, dan Imam Ahmad Ibn Hambal ${ }^{16}$.

Ditinjau dari pengertiannya, para ulama yang membolehkan hukuman $t a^{\prime} z \hat{\imath} r$ dengan cara mengambil harta, terutama dari Hanafiyah dengan redaksi:

"Hakim menahan sebagian harta si terhukum selama waktu tertentu, sebagai pelajaran dan upaya pencegahan atas perbuatan yang dilakukannya, kemudian mengembalikannya kepada pemiliknya apabila ia telah jelas taubatnya ${ }^{17 \prime \prime}$

Ditinjau dari macam-macamnya, Imam Ibn Taimiyah membagi hukuman ta'zir berupa harta ini kepada tiga bagian, dengan memperhatikan atsar (pengaruhnya) terhadap harta yaitu, menghancurkannya, mengubahnya atau memilikinya. Penghancuran barang ini tidak selamanya merupakan kewajiban, melainkan dalam kondisi tertentu boleh dibiarkan atau disedekahkan ${ }^{18}$. Atas dasar pemikiran ini, maka sekelompok ulama seperti Imam Malik dalam riwayat Ibn Al-Qasim, dengan menggunakan istihsan membolehkan itlaf (penghancuran) atas makanan yang dijual melalui penipuan dengan cara disedekahkan kepada fakir miskin, seperti Khalifah Umar pernah menumpahkan susu yang bercampur dengan air untuk dijual.

Dengan demikian dua kepentingan yaitu itlaf (penghancuran) sebagai hukuman dan manfaat bagi orang miskin, sekaligus dapat dicapai. Adapun hukuman ta'zir berupa mengubah harta pelaku antara lain seperti mengubah patung yang disembah oleh orang muslim dengan cara memotong bagian kepalanya, sehingga mirip dengan pohon. Hukuman $t a^{\prime} z i r$ berupa pemilikan harta penjahat (pelaku), antara lain seperti keputusan Rasulullah saw, melipat gandakan denda bagi seorang yang mencuri buah-buahan, disamping hukuman dera.

\footnotetext{
${ }^{16}$ Ahmad Wardi Muslich, Hukum Pidana Islam, 265.

17 Ibid., 266.

${ }^{18}$ Sudarsono, Pokok-Pokok Hukum Islam, (Jakarta: Pt.Rineka Cipta, 1992), 98.
} 
Seperti uraian yang telah dikemukakan di atas, khususnya pada bagian ketiga dari jenis ta'zir dengan harta, dapat diketahui bahwa wujud dari pemilikan harta itu adalah denda atau dalam bahasa Arab disebut gharamah. Maka hukuman denda sebagai salah satu jenis hukuman $t a^{\prime} z i r$ dalam syariat Islam.

Syariat Islam tidak menetapkan batas terendah atau tertinggi dari hukuman denda. Hal ini sepenuhnya diserahkan kepada hakim dengan mempertimbangkan berat ringannya jarimah yang dilakukan oleh pelaku. Secara terminologi, $t a^{\prime} z i r$ adalah bentuk hukuman yang tidak disebutkan ketentuan kadar hukumnya oleh syara' dan menjadi kekuasaan waliyyul amri atau hakim. ${ }^{19}$ Selain denda, hukuman $t a^{\prime} z i r$ yang berupa harta adalah penyitaan atau perampasan harta. Namun hukuman ini diperselisihkan oleh para fuqaha. Jumhur ulama membolehkannya apabila persyaratan untuk mendapat jaminan atas harta tidak dipenuhi. Syarat-syarat tersebut adalah sebagai berikut: ${ }^{20}$

a. Harta diperoleh dengan cara yang halal

b. Harta itu digunakan sesuai dengan fungsinya

c. Penggunaan harta itu tidak mengganggu hak orang lain.

Apabila persyaratan tersebut tidak dipenuhi, misalnya harta didapat dengan jalan yang tidak halal, atau tidak digunakan sesuai dengan fungsinya, maka dalam keadaan seperti itu, Ulil Amri berhak untuk menerapkan hukuman $t a^{\prime} z \hat{\imath} r$ berupa penyitaan atau perampasan sebagai sanksi terhadap perbuatan yang dilakukan oleh pelaku seperti kejahatan korupsi²1.

Di dalam fiqih sunnah dijelaskan diperbolehkannya bagi pemerintah untuk menakzir dengan menyita harta pelaku. Ini adalah pendapat Abu yusuf dan Malik. Pengarang $M u^{\prime} i n$ alHukkam berkata, "sungguh, orang yang mengatakan bahwa t $a^{\prime} z i r$ berupa penyitaan harta pelaku telah dihapus (dinasakh) adalah keliru dalam menukil dan mengambil dalil. Mereka menyalahi pendapat para imam. Tidaklah mudah menyatakan bahwa hal ini telah dihapus, karena mereka yang berpendapat seperti itu tidak memiliki sunnah maupun ijma' yang dapat mendukung statemen mereka. Mereka hanya berteriak, "Maszhab kami tidak memperbolehkannya"

Ibnu Qayyim berkata, “Nabi SAW, pernah menjatuhkan sanksi ta'zir berupa tidak memberikan jatah bagi orang yang mengambil terlebih dahulu. beliau juga menjelaskan ta'zir yang layak diberikan kepada orang yang enggan mengeluarkan zakat, maka ta'zir itu berupa penyitaan separuh hartanya, beliau bersabda. ${ }^{22}$

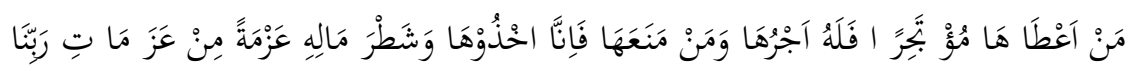

Artinya: Barang siapa yang menunaikan zakat dan menyedekahkan hartanya, ia mendapatkan pahalanya. Barang siapa yang enggan menunaikannya sungguh kita akan mengambil zakatnya bersama setengah kekayaannya sebagai hak Allah.

Maka dalam hal ini hukuman tambahan berupa ganti rugi menurut hukum pidana islam berdasarkan segi pertalian antara hukuman satu dengan hukuman yang lainnya termasuk pada kategori hukuman tambahan yang dikategorikan di dalam Uqubah Taba'iyah, yang berupa hukuman tambahan tanpa memerlukan putusan hakim secara tersendiri sedangkan, berdasarkan dari segi keharusan untuk memutuskan dengan hukuman tersebut

\footnotetext{
${ }^{19}$ Rahmat Hakim, Hukum Pidana Islam (Fiqih Jinayah) (CV. Pustaka Sena: Bandung, 2000), 140- 141.

${ }^{20}$ Ahmad Wardi Muslich, Hukum Pidana Islam.., 267.

${ }^{21}$ Ibid.,267.

${ }^{22}$ Sayyid Sabiq, Fiqih Sunnah 4, (Jakarta : Pena Pundi Aksara, 2012), 394.
} 
dapat dikategorikan sebagai Hukuman yang belum ditentukan ('Uqubah Ghair Muqaddarah), yaitu hukuman yang diserahkan kepada hakim untuk memilih jenisnya dari sekumpulan hukuman-hukuman yang ditetapkan Oleh syara' dan menentukan jumlahnya untuk kemudian disesuaikan dengan pelaku dan perbuatannya. Hukuman ini disebut juga Hukuman pilihan ('Uqubah Mukhayyarah), karena hakim dibolehkan untuk memilih diantara hukuman-hukuman tersebut.

Ditinjau dari segi tempat dilakukannya hukuman maka hukuman ini termasuk pada Hukuman harta ('Uqubah Maliyah), yaitu hukuman yang dikenalkan terhadap harta seseorang, seperti diat, denda, dan perampasan harta.

\section{Kesimpulan}

Dari uraian yang telah dipaparkan sebelumnya dapat disimpulkan bahwa penetapan pidana uang pengganti sebagai salah satu bentuk penghukuman dalam tindak pidana korupsi pada dasarnya ditujukan agar kerugian negara sebagai berikut perbuatan korupsi bisa diminimalisir atau mungkin dihilangkan. Pidana uang pengganti sebagai sebuah sebuah bentuk pemidanaan lahir atas dasar rasionalitas pembentuk undang-undang untuk meminimalisir kerugian keuangan negara, disamping juga tidak melupakan substansi pidana itu sendiri, yakni untuk memberi hukuman yang setimpal terhadap pelaku (dengan harapan berefek pencegahan).

Salah satu kepentingan hukum yang dipandang penting dan wajib dalam setiap kasus korupsi adalah bagaimana mengembalikan kerugian negara. Agar hal ini bisa dilaksanakan secara baik maka aparat penegak hukum harus bertindak cepat, profesional dan cermat khususnya dalam menghitung jumlah kerugian yang di timbulkan dalam sebuah kasus korupsi.

Disamping itu, penegakan hukum terhadap kasus korupsi, khususnya menyangkut penerapan dan pelaksanaan pidana uang pengganti dirasakan masih kurang maksimal dijalankan. Salah satu sebabnya karena pidana uang pengganti dirasakan masih kurang maksimal dijalankan.

\section{Daftar Pustaka}

\section{Buku}

Arief, Nawawi Barda. 2005. Perbandingan Hukum Pidana. Jakarta: PT RajaGrafindo Persada.

Audah, Abdul Qadir. Tanpa tahun. At-Tasyri' Al Jina'iy Al-Islamy. Beirut : Dar Al-Kitab Al'Araby

Ermanjah Djaja. 2008. Memberantas Korupsi Bersama KPK (Komisi Pemberantasan Korupsi). Bandung: PT Refika Aditama.

Hakim, Rahman.2000. Hukum Pidana Islam (Fiqih Jinayah), (Bandung: CV. Pustaka Sena)

Hamzah, Abdi.2008. Pemberantasan Korupsi. Jakarta : PT RajaGrafindo Persada.

Hanafi, Ahmad.1986. Asas-asas hukum pidana islam. Jakarta : Bulan dan Bintang.

Hartani, Evi .2008. Tindak Pidana Korupsi . Jakarta : Sinar Grafika.

Muslich, Ahad Wardi.2005. Hukum Pidana islam. Jakarta : Sinar Grafika.

Prodjpdikoro, Wirjono. 2003. Tindak-Tindak Pidana Tertentu Di Indonesia. Bandung : PT Refika Aditama..

Sabiq, Sabiq.2012. Fiqih Sunnah 4. Jakarta : Pena Pundi Aksara..

Sudarsono. 1992. Pokok-Pokok Hukum Islam. Jakarta: Pt.Rineka Cipta. 


\section{Perundang-undangan}

Undang-Undang Republik Indonesia Nomor 20 Tahun 2001 Tentang Perubahan Atas Undang-Undang Nomor 31 Tahun 1999 Tentang Pemberantasan Tindak Pidana Korupsi 